\title{
Variációk a kérésre 17-18. századi levelekben
}

\section{Bevezetés ${ }^{1}$}

A jelen tanulmányban Barkóczy Krisztina férjéhez írt leveleiben vizsgálom meg a kérés beszédaktusát, történeti szociopragmatikai keretben (a történeti szociopragmatikáról bővebben lásd: Sárosi 2003, 2015). Bemutatom, hogy a feleség Károlyi Sándorhoz intézett kérései (1) mire vonatkoznak, azaz mi a tárgyuk; valamint (2) a kérések megjelenítési módjával is foglalkozom, tanulmányozom, hogy mely stratégiák dominálnak a levelekben; valamint (3) megfigyelem, hogy felfedezhető-e összefüggés a kérések tárgya és a megformálásukra alkalmazott nyelvi stratégiák között. Végül egy újabb elmélet bevonásával a középmagyar kori kérések további megközelítési lehetöségére hívom fel a figyelmet.

Korábbi történeti szociopragmatikai kutatásaimban a kérés beszédaktusa kapcsán (vö. Bácsi 2015, 2019) 16. és 17. század eleji házastársi leveleket, továbbá 18. századi peregrinusleveleket elemeztem. Ennek eredményeként a mai magyarban gyakran használt kérési módokhoz képest jelentős eltéréseket kaptam, így jelenlegi célom, hogy további levelekből származó kérésekkel bővítve a már meglévő korpusz anyagát, ennek az időszaknak (17. század vége és 18. század eleje) az eredményeit összehasonlítsam a korábbi anyagokéival. Szeretném továbbá elméleti szempontból is kiterjeszteni a kutatásomat, így a lehetséges további feldolgozási módokra is utalok.

Először a kérések elemzési módjának elméleti hátterét ismertetem, majd a korábbi kutatások eredményeit vázolom fel. Ezután a most felhasznált levelek szerzőjét és levelezését mutatom be, majd az anyag feldolgozási módja és a hipotézisek következnek. Az eredményeket diagramok segítségével szemléltetem. A tanulmány végén a következtetések és a kitekintés szerepel.

\section{Elméleti keret, a kérés beszédaktusa}

A levelekben előforduló kérések elemzésénél a beszédaktus-elméletet, illetve BlumKulka, House és Kasper kilenc kategóriából álló osztályozását alkalmaztam (mindezek valamivel bővebben összefoglalva megtalálhatók: Bácsi 2015: 77-8). Austin elsőként állapította meg, hogy a nyelvi megnyilatkozások önmaguk is cselekvések (Austin 1990: 33). A beszélő megnyilatkozásának az illokúciós ereje határozza meg azt, hogy mit akar elérni az adott mondat kimondásával. A kérések ,,a beszélőnek arra irányuló szándékát jelenítik meg, hogy hallgatója megtegyen valamit" (Szili 2002: 12). Austin így a végrehajtók csoportjába (Austin 1990), Searle pedig be-

1 A tanulmány a 116217 számú OTKA-projektum anyagait felhasználva készült. Előadásként elhangzott a 13. Félúton konferencián az Eötvös Loránd Tudományegyetem Bölcsészettudományi Karán. Ezúton szeretnék köszönetet mondani doktori témavezetőmnek, Sárosi Zsófiának szakmai segítségéért. 
szédaktus-tipológiájában a direktívumok, azaz az utasítók közé helyezte a kéréseket, ugyanis a világot akarja a szavaihoz igazítani kimondásával a megnyilatkozó (Searle 1975; Tátrai 2011).

A CCSARP (Cross-Cultural Study of Speech-Act Realization Patterns) volt az első olyan nemzetközi vállalkozás, amely 1982-ben a kérés beszédaktusát nyolc nyelvben elemezni kezdte. Ebben a projektben a kérések szerkezetét három kisebb részre bontották. Az első egység a megszólító, avagy figyelemfelkeltő kifejezés, a második a fó cselekmény, amely a tulajdonképpeni kérést tartalmazza, a harmadik pedig a kötőelemek vagy más megnevezésben a támogató lépések, amelyek alátámasztják, indokolják a kérést. A vizsgálatok legtöbbször a fó cselekményt tanulmányozzák (Blum-Kulka-House-Kasper 1989; Szili 2002: 17). Jelen kutatásomban én is így járok el.

A Blum-Kulka, House és Kasper szerzőhármas is a fő cselekményt vette górcső alá, és a legdirektebbtől a legközvetettebbig haladva kilenc stratégiáját különítette el a kérési szándék megjelenítési módjának (Blum-Kulka-House-Kasper 1989: 278-80; Szili 2002: 17-8):

1. A legközvetlenebb stratégia a származtatott mód (1). Ennél a kategóriánál a kérés illokúciós erejét legtöbbször a felszólító mód, de emellett annak funkcionális megfelelői, a fónévi igenév és az elliptikus mondatszerkezetek jelenítik meg (pl.: Ne tessék dohányozni!).

2. A második csoport az explicit performatívum (2). Ilyenkor a beszélő szándéka expliciten, az illokúciót megjelenítő igével, a kér performatív igével jelenik meg (pl.: Kérlek, segits).

3. Beágyazott performatívumnál (3) a kérés szándékát jelölö ige (kér) módosult formában, modális igével vagy egyéb segédigeszerü elemekkel fejeződik ki (pl.: El kell, hogy kérjem a tollad).

4. Származtatott lokúciókor (4) az illokúciós szándék a lokúció jelentéséből tudható meg (pl.: Engem is elvisz? 'vigyen el').

5. Akaratnyilvánítás (5) esetén a beszélőnek az a szándéka mutatkozik meg, hogy bekövetkezzen a propozícióban bennfoglalt esemény (pl.: Szeretnék telefonálni a mobiloddal).

6. Ezt követi a leginkább hallgatóorientált, diplomatikus javaslattevő forma (6) (pl.: Mi lenne, ha kitakaritanánk?).

7. Az előkészítő stratégiában (7) olyan alakzatok kapnak helyet, amelyek az elutasítástól való félelmünket bizonyítják. Megformálására az alábbi konvencionális alakok szolgálnak: olyanok, amelyekkel ellenőrizhető a hallgató képessége (7a) (pl.: El tudna vinni?), tesztelhető a hajlandósága (7b) (pl.: Elvinne?), a megvalósítás lehetősége iránt is érdeklődhet (7c) a kérö (pl.: Lehetséges lenne, hogy...?), valamint az engedélykérés (7d) is itt szerepel, ez a típus az eredeti csoportosításban nem fordul elö, Szili Katalin viszont felveszi (pl.: Megengedi, hogy...).

8. Erôs célzásnál (8) az illokúciós erő nem következtethető ki közvetlenül a lokúcióból, de a lokúcióban azért megjelennek a szándékolt aktus lényeges elemei (pl.: Van apród? [pénzfelváltás előtt]). 
9. Gyenge célzás (9) esetén ellenben a lokúcióban nem fedezhetők fel a végrehajtandó aktusról a lényegi elemek (pl.: Jó sokan fürödhettek itt 'Piszkos a fürdőszoba, takarítsd ki!') (Blum-Kulka-House-Kasper 1989: 278-80; Szili 2002: 17-8).

\section{Korábbi kutatások a kérés beszédaktusáról}

A Blum-Kulka, House és Kasper szerzőhármas csoportosítását felhasználva több, a mai magyar nyelvre kiterjedő vizsgálat született (vö. Szili 2002, 2004; Boronkai 2006, 2009). Szili Katalin kutatásában a kérések fó cselekményének osztályozásakor a származtatott mód (1), az elökészítő stratégia (7), valamit a beágyazott performatívum (3) dominanciáját állapította meg. 10\% alatt jelentek meg az explicit performatívum (2) és az erős célzás (8) csoportjába sorolható kérések. A többi stratégia jóval csekélyebb arányban adatolható. Érdekesség, hogy a beszélő és a hallgató közötti társadalmi távolság növekedésével (külső kontextuális tényezők) a közvetettebb stratégiák alkalmazása vált jellemzővé, továbbá a kérés súlya, a beszélő jogai (belső kontextuális tényezők) is viselkedésmódosító szereppel rendelkeztek (Szili 2002: 18-21).

Boronkai Dóra férfiak és nők kéréseit hasonlította össze. A férfiak elsősorban a származtatott módot (1), valamint a származtatott lokúciót (4) hívták segítségül nők felé intézett kéréseik létrehozásakor, de szívesen alkották meg kéréseiket beágyazott performatívummal (3) is. A nök egyenrangú féllel szemben direkt stratégiákat használtak, elsősorban származtatott módot (1) és explicit performatívumot (2), felettük álló félhez fordulva pedig a kevésbé direkt beágyazott performatívumot (3) és az előkészítő stratégiát (7) részesítették előnyben. Gyakori volt az előkészítő stratégia (7) alkalmazása akkor is, ha egyenrangú partnerhez intézték kéréseiket, ami az udvariasságuk bizonyítéka (Boronkai 2006: 76-7).

Olyan történeti kutatások, amelyek a kérés beszédaktusát a Blum-Kulka, House és Kasper szerzőhármas felosztása alapján vizsgálták, jóval kisebb számban születtek. Krepsz Valéria 16-18. századi nemesi és nem nemesi levelekben tanulmányozta a kéréseket. A direktebb módok jelenlétét figyelte meg a misszilisekben. Nagy arányban jelentkezett explicit performatívum (2), de származtatott móddal (1) is lehetett találkozni az írásokban (Krepsz 2015: 170).

Korábbi munkáimban 16-18. századi missziliseket elemeztem. A mai magyar eredményekhez képest én is jelentős eltérésekre figyeltem fel. A házastársak és a peregrinusok kéréseinél a származtatott mód (1) dominanciája volt jellemző, illetve az explicit performatívum (2) is nagy arányban megjelent, ellenben a mai magyarban gyakori előkészítő stratégia (7) és beágyazott performatívum (3) nem vagy alig szerepelt a kérések megalkotásakor. Meghatározó volt még a házaspárok írásaiban a származtatott lokúció (4) és az akaratnyilvánítás (5) jelenléte is, míg a külföldön tanuló diákok kéréseinél a származtatott lokúció (4) és az erős célzás (8) kategóriái. A direkt formák alkalmazása, a távolság hiánya valószínúleg ebben a korban semleges, sőt pozitív értékkel bírt (Bácsi 2015, 2019). A házastársak leveleiben 
a férjek és a feleségek kérései között különbségek fedezhetők fel. Ez eltérő társadalmi szerepükből is fakad, hiszen a korban a nők a férfiaknak voltak alárendelve. A férjek a legtöbbször a legdirektebb stratégiával, a származtatott móddal (1) formálták meg kéréseiket, csak akkor alkalmaztak kevésbé direkt kérési módokat, ha valamit nagyon szerettek volna, vagy ha kérésük nagyon fontos volt. A feleségek ellenben a kevésbé direkt stratégiát, az explicit performatívumot (2) alkalmazták, és csak akkor szólították meg párjukat egyszerü felszólító móddal, azaz származtatott móddal (1), ha úgy érezték, hogy kérésük jogos (Bácsi 2015).

A történetiségben jelentkező direkt stratégiáknak a nagy számú használata nem példa nélküli más nyelvek esetében sem. 17-18. századi bírósági tárgyalások és színdarabok kéréseinél is a legközvetlenebb, a származtatott mód (1) dominanciáját állapította meg Culpeper és Archer a mostanában gyakori, indirekt, előkészítő stratégiával (7) szemben (Culpeper-Archer 2008: 76-80), továbbá Kohnen is a direktebb stratégiák jelenlétét mutatta ki a korábbi angol kultúrában (Kohnen 2008: 39-40).

\section{Barkóczy Krisztina levelei férjéhez, Károlyi Sándorhoz}

Kutatásomban Barkóczy Krisztina férjének szóló leveleit dolgoztam fel. Ahhoz, hogy a bennük található kéréseket pontosan elemezni lehessen, szükség van a feleség családi hátterének, valamint a levelek megírási körülményeinek az ismeretére.

Barkóczy Krisztina Szalai Barkóczy György bárónak és Koháry Juditnak volt a gyermeke. Édesapja főispánként és katonaként tevékenykedett, édesanyja pedig nagyon vallásos és adakozó nő hírében állt. A lány szülei nyomdokát követve egész életében nagy gondot fordított a szegények segítésére és a katolikus vallás gyakorlására. 16 évesen ment hozzá 1687. június 17-én a nála két évvel idősebb Károlyi Sándorhoz. Nem érdekházasság volt az övék, és ez a levelekből is kiderül (Takáts 1910: 14-38). Károlyi minden örömét és bánatát megosztotta feleségével, és az aszszony is így tett. Mivel házasságuk alatt sokszor voltak távol egymástól, levelekben tartották a kapcsolatot.

Ezekben beszámoltak egymásnak az általuk tudott hírekről. Károlyi Sándor általában a hadi helyzetről tudósította feleségét, Barkóczy Krisztina pedig a tiszántúli megyék vezetéséről és a lakosság életéröl informálta a férjét. Emellett családtagjai és saját betegségéről, a ház körüli teendőkről, családi ügyekről írt. Az asszony levelei nagyobb arányban maradtak fenn, mint Károlyi Sándoréi. Ennek egyik lehetséges magyarázata, hogy maga Barkóczy Krisztina semmisítette meg férje írásait az emigrációra készülve (Kovács 2011: 7-8).

\section{Vizsgált anyag, módszer és hipotézisek}

Barkóczy Krisztina férjének, Károlyi Sándornak írt 100 levelét vizsgáltam meg, amelyek a 17. század végén és a 18. század elején keletkeztek. Az elemzéshez a Történeti magánéleti korpusz anyagát használtam fel (Dömötör-Gugán-Novák-Varga 
2017; Novák-Gugán-Varga-Dömötör 2018). A misszilisek több mint felében, 63\%ában szerepelt valamilyen kérés. Összesen 144 kérést tartalmazott ez a 63 levél, amelyeket elemeztem tárgyuk alapján, továbbá tanulmányoztam a kérések módját is. A fó cselekményeket helyeztem a kutatás középpontjába, ezeket soroltam be a Blum-Kulka, House és Kasper által megalkotott csoportokba.

Korábbi vizsgálati eredményeimből kiindulva, amikor hasonlóan egymástól sokszor távol élő házaspárok kéréseit kísértem figyelemmel, elsősorban a valamilyen cselekedetet, intézkedést, illetve a tárgyat kérő kérések nagy arányára számítottam. Jelentősnek gondoltam továbbá a levélírást sürgető kéréseket, valamint a kérlelő, hazajövetelt szorgalmazó kéréseket is.

A mai magyarban jellemző kérési módokhoz képest a direktebb stratégiák dominanciáját vártam, hiszen a történeti anyagnál eddig ez a típus volt a meghatározó. Elsősorban az explicit performatívum (2) nagyarányú jelenlétére számítottam, hiszen a korábbi korokban a nők ezzel a tiszteletteljesebb alakkal fordultak férjük irányába, megadva nekik a „hatalmi fölényt”. A származtatott mód (1) meghatározó voltát is elvártam, valamint kiemelkedő eredményeket véltem a származtatott lokúció (4) és az akaratnyilvánítás (5) szerepeltetésénél is. A kérések tárgya és megjelenítési módja között kapcsolatot feltételeztem.

\section{Eredmények}

\subsection{A kérések tárgya alapján}

Megvizsgáltam, hogy mire irányulnak a levelekben található kérések, így tárgyuk alapján négy kategóriát hoztam létre: cselekedet, intézkedés kérése; személy vagy tárgy kérése; levélírás kérése és bizalom kérése.

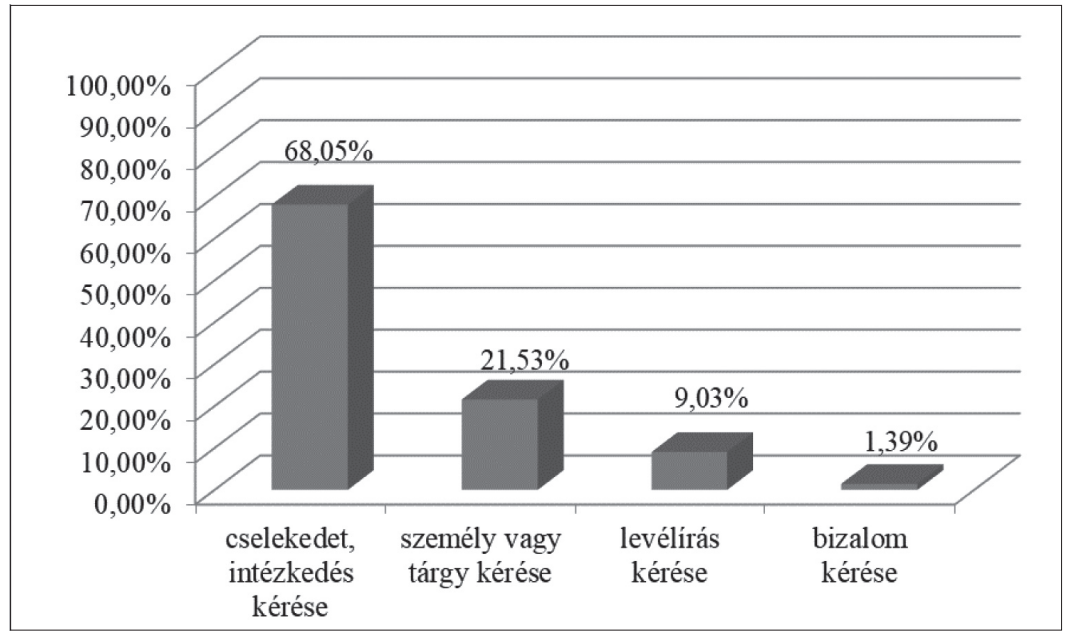

1. ábra. A kérések megoszlása a kérés tárgya alapján 
Az 1. ábrán is látható, hogy legnagyobb számban a cselekedet, intézkedés kérése jelent meg a levelekben. Barkóczy Krisztina kéréseinek több mint felében, 68,05\%ában (98 db) kérte meg Károlyi Sándort, hogy intézkedjen valamilyen ügyben, amelyet csak a férfi tudott teljesíteni. Így volt ez a következő esetben is:

(1) 1705: Az salánki oroszoknak valami harangot ígért volt Kegyelmed, Édesem. Ha valamely nem unitus rácok harangját kaphatnák, jó volna odaadni (Bark. 49.). ${ }^{2}$

Többször kérte a férjét, hogy segítsen a szegényeknek és az árváknak, hiszen magas pozíciója révén erre volt lehetősége, például:

(2) 1705: Hasonlóképen a szegíny Ibrányi Uram árváirul se feledkezzék el Kegyelmed, Édesem (Bark. 46.).

(3) 1706: Kérem, Édes Lelkem, ha mibe lehet, szolgáljon szegínynek (Bark. 96.).

A birtokuk körül dolgozóknak is szerette volna, hogy parancsoljon a férfi, hiszen az úrnak volt elöttük tekintélye:

(4) 1706: Ha még nem töt volna Kegyelmed dispositiót, parancsoljon iránta (Bark. 89.).

(5) 1706: Arul is parancsoljon Kegyelmed, Szívem (Bark. 89.). ${ }^{3}$

Sokszor kérte Károlyi Sándort, hogy küldjön neki haza egy otthonról hiányzó személyt, munkást vagy valamilyen tárgyat, elsősorban ruhát és ahhoz való anyagot, amelyet ő nem tudott megszerezni. 21,53\%-át (31 db) kéréseinek ez a típus adta. Béresekre volt szüksége az előbbi esetben, míg az utóbbi példában német munkás megkeresését és küldését kérte:

(6) 1706: S ha béreseknek való leginyeket szereztethetne is Kegyelmed, Édesem, küldene (Bark. 85.).

(7) 1705: Ha valami mesterember találtatnék vagy akadna föképen német, küldene Kegyelmed, aki igazgatná a többit is, mert a csatornák miá az istálló, konyhaház s a többi is elromlot, úgyhogy építeni kel (Bark. 48.).

A következő példákban konkrét tárgyat, ruhát és hozzá illő anyagot kért a feleség:

2 A hivatkozás az év és a kötet Történeti magánéleti korpuszban (TMK: http://tmk.nytud.hu/) alkalmazott rövidítése és a levél száma alapján történik. A példákat a korpusz és a kötet szerint betűhüen közlöm.

3 Érdemes lenne a későbbiekben tanulmányozni a kérésekhez tartozó megszólításokat és azoknak a bizalmas kiegészítéseit (pl.: Édesem, Édes Lelkem, Szívem), ugyanis ezek vizsgálata biztosan további adalékot szolgáltatna a kérések megértéséhez, de a jelen kutatás során a kérések fó cselekményét mutatom be. 
(8) 1703: Franciakék anglia Debrecenben nem lévén, oda kerestessék Kegyelmed, mert másra nem szeretem a cafragot (Bark. 11.).

(9) 1699: Édesem, hozzon Kegyelmed olyan réz galandot, mint Orosz Pál Uram hozott volt (Bark. 7.).

Előfordultak még levélírást sürgető kérések is az asszony leveleiben. 9,03\%-át (13 db) a kéréseinek ez tette ki. Nagyon várta, hogy írjon neki a férje, hiszen amikor Károlyi Sándor távol volt az otthontól, így tudtak kommunikálni egymással, így informálták a másikat a hogylétükről, és így értesítették egymást az országban történtekről. Érthető tehát, hogy fontos volt Barkóczy Krisztinának, hogy férje minél többször küldjön neki levelet:

(10) 1704: Édesem, tudósítson Kegyelmed gyakraban [...] (Bark. 24.)

(11) 1706: Azért, Szívem, tudósítson Kegyelmed mennél hamarab, hogy felmehessek (Bark. 99.).

Egy-egy példával képviseltették magukat a levelekben a bizalmat kérő kérések, ez 1,39\%-ot ( 2 db) jelent. Érdekesség, hogy ezt a típust korábbi kutatásaim szerint csak férfiak alkalmazták. Barkóczy Krisztina leveleiben, a megelőző tapasztalataimmal ellentétben, a feleség kérte a férjét, hogy bízzon benne, minden ház körüli teendőt elintéz:

(12) 1698: Édes Lelkem, ne gondolkozzék Kegyelmed, mert az Kegyelmed parancsolatjában mindenek eljárnak velem együtt, az mint legjobban lehet (Bark. 3.).

A következő esetben szerette volna, ha Károlyi Sándor nem aggódik iránta, hanem bízik benne, hogy minden rendben lesz:

(13) 1703: Énrajtam ne gondolkozzék, gondot visel Isten reánk s az hírekrül tudósítson (Bark. 15.).

\subsection{A kérések megjelenítési módja alapján}

A Blum-Kulka, House és Kasper szerzőhármas elméletét alapul véve besoroltam a kéréseket a kilenc stratégia megfelelö csoportjaiba. A 2. ábráról is leolvasható, hogy hat típusra találtam példát a levelekben.

A leginkább domináns kérési fajta a legdirektebb forma volt a misszilisekben. Barkóczy Krisztina a legközvetlenebb kategóriát, az egyszerü felszólító módot alkalmazta kéréseinek több mint a felénél, 62,5\%-ánál (90 db). Ha valamit szeretett volna kérni a férjétől, azt legtöbbször a származtatott mód (1) segítségével tette: 


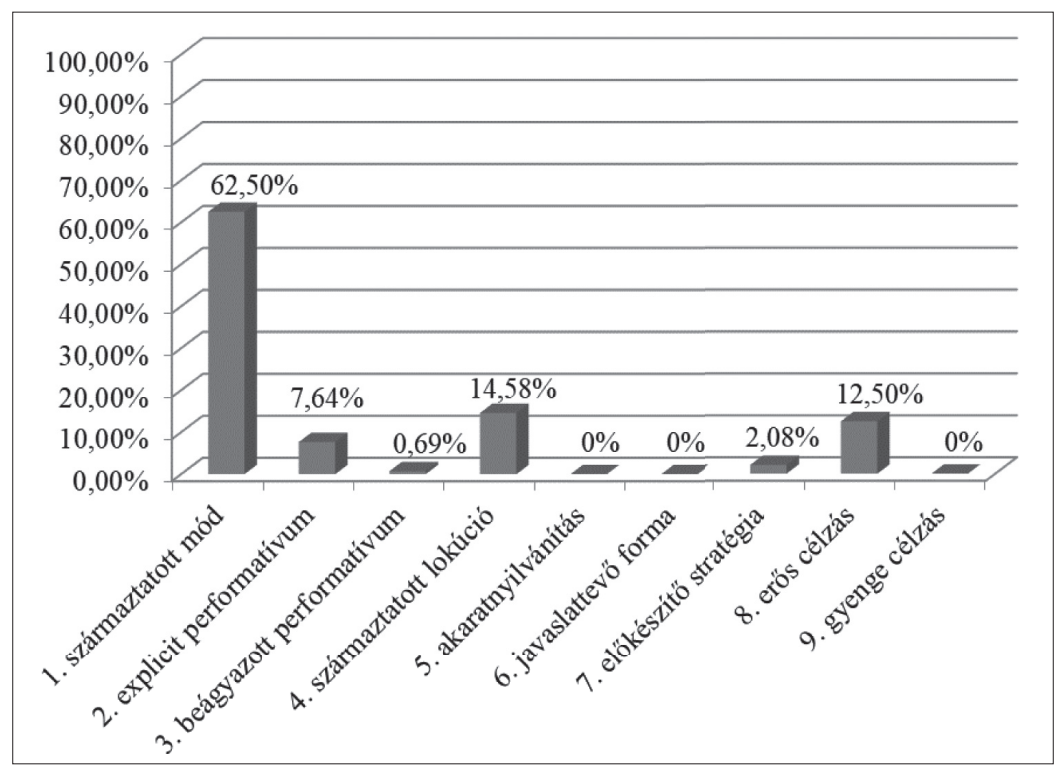

2. ábra. A kérések megoszlása a kérési szándék megjelenítési módjai alapján

(14) 1705: Küldje el Kegyelmed, Szívem, mert nem is tudom, mi van benne (Bark. 44.).

(15) 1705: Azonba, Édesem, hozasson Kegyelmed egy eskető parancsolatot, Szakmár és Szabolcs vármegyére szóllót, had esketessek a károlyi elprédált jovaink felől (Bark. 56.).

Bár a történeti anyag kapcsán a direkt típus uralkodó voltát vártam, mégis korábbi kutatásaim eredményeiből kiindulva az explicit performatívum (2) elsődleges szerepeltetésére számítottam, hiszen ez volt a legjellemzőbb típus a feleségek leveleiben a 16-17. századi házastársi levelekben. Itt viszont a legdirektebb formáé, a származtatott módé (1) volt a vezető szerep, az explicit performatívum (2) pedig kis számban jelent meg, amely szokatlan jelenségnek mondható.

Nagy arányban jelentkeztek származtatott lokúciót (4) tartalmazó kérések a feleség írásaiban, ugyanis 14,58\%-át (21 db) a kéréseknek ez a típus adta. Ez a kevésbé direkt stratégia szerepel a következö példákban is:

(16) 1704: Az olcsvai tornyocskára is lehetne ottan bádogot szerzeni (Bark. 20.).

(17) 1705: Bár szerzene vagy három heverő katonát soldosnak, mert nem kaphatni (Bark. 63.).

Érdekes, hogy az asszony leveleiben meghatározók voltak az indirekt, erős célzást (8) magukban foglaló kérések is, amelyek eddig nők leveleiben nem fordultak elő. 12,5\%-a (18 db) a kéréseknek így fejeződött ki: 
(18) 1698: Szakmári Uram valóba vágyna egy szőrövre (Bark. 5.).

(19) 1698: Édes Szívem, hogy Kegyelmed harmad napig sem megyen templomba, Isten panaszá ne vegye. Én annak nem örülök, mertha Istent a dologért elhagyjuk, félö, az Isten is el ne hagyjon. Hanem adja meg ember az Istennek, ami Istené, a császárnak is, ami a császáré (Bark. 5.).

A korábban a nők kéréseiben olyan gyakori explicit performatívum (2) Barkóczy Krisztina leveleiben csupán a negyedik helyet foglalta el a kérési módok között. Jelenléte még a 10\%-ot sem érte el, ugyanis 7,64\%-os (11 db) arányban jelentkezett a misszilisekben. Jó példák erre a típusra a következők:

(20) 1704: Édesem, kérem szeretettel Kegyelmedet az Istenért, az káromkodó szitoktul őrizkedjen, mert az szófogadatlanok közt, elhiszem, nehéz magát megfogni s talám nem is volna oly iszonyú vétek, mint más alkalmatosságba, de hogy Kegyelmed Fő, s másoktul is tiltani kel, abbul rosz példát vesznek s nem is büntetheti osztán (Bark. 24.).

(21) 1705: Már csak abbahattam, hanem, Szívem, kérem Kegyelmedet, ha maga nem érkezik is, ha lehet, bízza valakire az hevesi dolgot (Bark. 38.).

Csupán pár adat képviselte a mai magyarban döntő szerepet betöltő csoportokat, az elökészítő stratégiát (7) és a beágyazott performatívumot (3). Az elöbbi a kérések 2,08\%-át (3 db), az utóbbi pedig a 0,69\%-át ( $1 \mathrm{db}$ ) jelentette. Elökészítő stratégiára (7) példa: 1705: „A mentét, Szívem, megcsináltathatom a téglaszínhez, de dolmány itten nem lévén, mértéket küldene, Szívem, Kegyelmed, akit szabó mérne meg, mert az elei rámán esnék megvarni, de az igen hamar lenne” (Bark. 57.). Beágyazott performatívum (3) figyelhető meg a következő esetben: 1704: „Az Istenért, Szívem, az Méltóságos Fejedelmet kén kérni, lenne job rendelés Szakmárrul” (Bark. 28.). Ez a csekély szám nem meglepő, korábbi kutatásaimban is ilyen eredményt kaptam.

\subsection{A kérések tárgya és megjelenítési módja}

Megvizsgáltam, hogy mutatkozik-e összefüggés a kérések tárgya és a kérések megjelenítési módja között, amelyet egy táblázat segítségével is bemutatok. Az 1. táblázat is jól szemlélteti, hogy mind a cselekedet, intézkedés, mind a személy vagy tárgy, mind a levélírás és mind a bizalom kérésénél a legnagyobb arányban a származtatott módot (1) használta Barkóczy Krisztina. Ha tehát a férjétől bármit kért, azt általában a legdirektebb módon tette.

Érdekes viszont, hogy a kevésbé közvetlen megjelenítési módokat, az előkészítő stratégiát (7) és az erős célzást (8) legtöbbször személy vagy tárgy kérése esetén, illetve levélírásra felszólításkor alkalmazta. Ezeket az adatokat félkövérrel szedtem a táblázatban. 
1. táblázat. A kérések tárgya és megjelenítési módja

\begin{tabular}{|l|c|c|c|c|}
\hline & $\begin{array}{c}\text { Cselekedet, } \\
\text { intézkedés kérése }\end{array}$ & $\begin{array}{c}\text { Személy vagy } \\
\text { tárgy kérése }\end{array}$ & $\begin{array}{c}\text { Levélírás } \\
\text { kérése }\end{array}$ & $\begin{array}{c}\text { Bizalom } \\
\text { kérése }\end{array}$ \\
\hline 1. származtatott mód & 66 & 13 & 9 & 2 \\
\hline $\begin{array}{l}\text { 2. explicit } \\
\text { performatívum }\end{array}$ & 10 & 0 & 1 & 0 \\
\hline $\begin{array}{l}\text { 3. beágyazott } \\
\text { perfomatívum }\end{array}$ & 1 & 0 & 0 & 0 \\
\hline $\begin{array}{l}\text { 4. származtatott } \\
\text { lokúció }\end{array}$ & 12 & 9 & 0 & 0 \\
\hline 7. előkészítő stratégia & 1 & $\mathbf{2}$ & 0 & 0 \\
\hline 8. erós célzás & 8 & $\mathbf{7}$ & $\mathbf{3}$ & 0 \\
\hline
\end{tabular}

Valószínűleg jogosnak tartotta az asszony a kérését, ha olyan intézkedés megtételére kérte a férfit, amelyet csak ő tudott elintézni magas pozíciója vagy távolléte miatt, így ilyenkor a felesége megfelelőnek tartotta a közvetlen, direkt megszólítási módot (1). Ám ha valamilyen tárgy vagy személy megküldését kérte Károlyi Sándortól, továbbá amikor levélírásra buzdította őt, több esetben „illendőbbnek” találhatta az indirekt formák $(7,8)$ szerepeltetését, hiszen ezen kérések közül nem mindegyik volt sürgős, nem mindegyik volt ,,jogos”, néha általában csak egy olyan vágy volt, amely vagy neki vagy más személynek lehetett fontos, ezért is jelent meg az indirektebb megjelenítési mód, például: 1698: „Szakmári Uram valóba vágyna egy szörövre" (Bark. 5.).

\section{7. Összegzés}

Jelen tanulmányban Barkóczy Krisztina férjéhez, Károlyi Sándorhoz írt 100 levelében vizsgáltam meg a kéréseket. Elemeztem a kérések tárgyát, valamint a megjelenítési módjukat. A dolgozat elején megfogalmazott elvárásaim közül volt olyan, amely beigazolódott, de olyan is akadt, amely nem bizonyosodott be.

Az asszony kérései valóban a legnagyobb arányban valamely cselekedet és intézkedés megtételére szólították fel a férjet, amelyet ő vagy távolléte miatt, vagy magas pozíciója révén meg tudott tenni a feleségével ellentétben. Jelentős volt még a valamilyen személy vagy tárgy küldésének a kérése is a levelekben, amely általában hiányzott otthonról Barkóczy Krisztinának. Levélírást szorgalmazó kérések is helyet kaptak az anyagban, ami nem véletlen, hiszen a pár levelek útján kommunikált, ha távol voltak egymástól, így fontos volt a rendszeres levélváltás. Az általam korábban feldolgozott 16-17. századi női kéréseknek nagy számát tette ki a kérlelő, a férfi hazajövetelét szorgalmazó kérési típus. Figyelemre méltó volt, hogy itt ez a kategória nem jelent meg, ellenben előfordultak bizalmat kérő kérések, amelyek használata megelőző kutatásaimban a férjekre volt jellemző. 
A kérések megjelenítési módjánál is bizonyos esetekben a várt eredményeket kaptam, de az írásom elején megfogalmazott hipotéziseimhez képest különbségekkel is találkoztam. Valóban a direktebb kérési stratégiák uralták a feleség kéréseit, valamint a mai magyarban gyakori kérési módok (előkészítő stratégia [7] és beágyazott performatívum [3]) itt sem mutattak kiugró értéket, mint ahogyan ez az eddigi történeti anyagot is jellemezte. Így valószínűnek látszik, hogy a 17. század végén és a 18. század elején is a direktebb formák alkalmazása semleges, sőt pozitív értékkel bírhatott.

Bár a direktség dominált a feleség leveleiben, de nem a várt explicit performatívum (2), amely korábbi kutatásaimban a nők által legtöbbet használt kérési típust adta, hanem a legdirektebb, a származtatott mód (1) fordult elő legnagyobb arányban a levelekben. Az asszony legtöbbször ezt alkalmazta, ha szeretett volna kérni valamit a férjétől. Az explicit performatívum (2) csupán a negyedikként szerepelt a sorban a kérések megformálásakor, ezt ugyanis megelőzte a közvetettebb származtatott lokúció (4) és az erős célzás (8) is. A származtatott lokúció (4) jelentős voltára korábban is számítottam, ám az erős célzás (8) nem jelent meg a nők kéréseiben az eddigi eredményeim szerint. Bár úgy véltem, hogy az akaratnyilvánítás (5) is meghatározó lesz, a jelenleg átnézett misszilisekben nem fordult elö ez a típus. Mindezen jelenségek pontos magyarázatára, okainak megadására további kutatások szükségek, felhasználva több, az asszonytól származó, valamint a férje által írt levelet is.

A kérések tárgyát és megjelenítési módját összevetve, kimutatható összefüggés. A legdirektebb stratégiát akkor alkalmazta Barkóczy Krisztina, ha kérését ,jogosnak” érezte, ellenben ha olyan kéréssel fordult Károlyi Sándor irányába, amelyet kevésbé érzett indokoltnak, csupán a kérö félnek volt fontos, egyfajta vágy volt csupán, akkor a közvetett alakokat részesítette előnyben. Ennél az anyagnál is látható tehát, hogy a belső kontextuális tényezők (a feleség vélt vagy valós jogai egy-egy kérés esetében) viselkedésmódosító szereppel rendelkeztek (vö. Szili 2002; Bácsi 2015).

\section{További kutatási lehetőségek, kitekintés}

Kutatásaim célja, hogy történeti szociopragmatikai keretben mutassam be a kérés megfogalmazásának módjait a középmagyar kori misszilisekben, hogy feltárjam a kérés megformálásának jellegzetességeit a vizsgált forrásokban, és ez alapján megállapítsam e beszédaktus végrehajtásának a korban, az adott müfajban, a társadalmi csoportokban és a társadalmi nemeknél szokásos módjait, valamint az ezektől való eltérések módjait és pragmatikai (vagy egyéb) okait.

Ehhez forrásként nemesi (elsősorban házastársi) és peregrinusleveleket vizsgáltam, de a források körét folyamatosan bővítem további, részben az eddigiekhez hasonló, részben más típusú levelezések bevonásával (nemesi levelek, jobbágylevelek, végvári levelek stb.) azért, hogy valóban átfogó és hiteles képet adhassak a középmagyar kori kérésekröl.

A középmagyar korban a különböző szituációs kontextusokban szokásosnak, megfelelönek - helyénvalónak - tartott vagy éppen attól valamilyen okból, célból és módon eltérö kéréseknek a kompetens leírásához és pragmatikai értelmezéséhez 
a felhasználtakon kívül célszerü újabb elméleti kereteket és szempontokat is bevonni a kutatásba, mégpedig a kapcsolati munka fogalmát és ezzel együtt valamennyire az udvariasság- és udvariatlanságelméleteket is.

Locher és Watts a kapcsolati munkát olyan „munkaként” definiálják, amelyet „az egyének fektetnek a másokkal való kapcsolataikról való egyezkedésbe, azaz a kapcsolati munka számukra a személyközi viszonyokról és jelentésekről való egyezkedés eszköze és színtere" (Szalai 2009: 179; Locher-Watts 2005: 10). Az udvariasságot és az udvariatlanságot társadalmilag jelölt viselkedésnek tartja a szerzőpáros, és ebben a tágabb keretben, a minden interakcióban jelen lévő kapcsolati munka részeként elemzik. Locher és Watts nem tekintik azonos kategóriáknak az udvariasság és a helyénvalóság fogalmát. A helyénvaló viselkedés nem feltétlenül udvarias is (Szalai 2009: 178-9; Culpeper 2011: 22-4).

Az eddig feldolgozott anyagok alapján úgy tünik, hogy a kéréseknél alkalmazott direkt megjelenítési forma semleges értékkel bírt a középmagyar korban, tehát valószínűleg ez lehetett a helyénvaló viselkedés akkoriban. Udvariasnak pedig az indirekt kérési formák számítottak. A kibővített források vizsgálata és a megnevezett elméleti keretekben történő elemzés során dől majd el, hogy a fenti megállapítások általános érvényünek tekinthetők-e.

\section{SZAKIRODALOM}

Austin, John L. 1962. How to Do Things with Words. Harvard University Press, Cambridge. Magyarul: Austin, John L. 1990. Tetten ért szavak. Akadémiai Kiadó, Budapest.

Bark. = Fogarassy Zoltán - Kovács Ágnes (szerk.) 2011. Barkóczy Krisztina levelei férjéhez, Károlyi Sándorhoz. Első kötet (1698-1711). Kapitális Kft., Debrecen.

Bácsi Enikő 2015. A kérési szándék megjelenítési módjainak vizsgálata egy 16. század második felében folytatott házastársi levelezésben. In: P. Kocsis Réka - Szentgyörgyi Rudolf (szerk.): Anyanyelvünk évszázadai 1. ELTE Magyar Nyelvtörténeti, Szociolingvisztikai, Dialektológiai Tanszék, Budapest, 75-89.

Bácsi Enikő 2019. Peregrinuslevelekben szereplő kérések nyelvi megformáltsága. In: Forgács Tamás - Németh Miklós - Sinkovics Balázs (szerk.): A nyelvtörténeti kutatások újabb eredményei X. Szegedi Tudományegyetem Magyar Nyelvészeti Tanszék, Szeged, 19-31.

Blum-Kulka, Shoshana - House, Juliane - Kasper, Gabriele (eds.) 1989. Cross-cultural pragmatics: requests and apologies. Ablex Publishing Corporation, Norwood.

Boronkai Dóra 2006. A „genderlektusokról” egy szociolingvisztikai diskurzuselemzés tükrében. Szociológiai Szemle 4: 64-87.

Boronkai Dóra 2009. Bevezetés a társalgáselemzésbe. Ad Librum, Budapest.

Culpeper, Jonathan - Archer, Dawn 2008. Requests and directness in Early Modern English trial proceedings and play texts, 1640-1760. In: Jucker, Andreas H. - Taavitsainen, Irma (eds.): Speech Acts in the History of English. John Benjamins Publishing Company, Amsterdam/Philadelphia, 45-84. https://doi.org/10.1075/pbns.176.05cul

Culpeper, Jonathan 2011. Politeness and impoliteness. In: Aijmer, Karin - Andersen, Gisle (eds.): Sociopragmatics, Volume 5 of Handbooks of Pragmatics. Mouton de Gruyter, Berlin, 391-436. Elérhetö: http://eprints.lancs.ac.uk/64460/1/Culpeper HOP_Politeness_longoverviewfinall.pdf (Letöltve: 2020. január 14.) https://doi. org $/ \overline{0} .1515 / 9783110214420.393$ 
Dömötör Adrienne - Gugán Katalin - Novák Attila - Varga Mónika 2017. Kiútkeresés a morfológiai labirintusból - korpuszépítés ó- és középmagyar kori magánéleti szövegekből. Nyelvtudományi Közlemények 113: 85-110.

Kohnen, Thomas 2008. Directives in Old English: Beyond politeness? In: Jucker, Andreas H. - Taavitsainen, Irma (eds.): Speech Acts in the History of English. John Benjamins Publishing Company, Amsterdam/Philadelphia, 27-44. https://doi.org/10.1075/ pbns.176.04koh

Kovács Ágnes 2011. Bevezetés. In: Fogarassy Zoltán - Kovács Ágnes (szerk.): Barkóczy Krisztina levelei férjéhez, Károlyi Sándorhoz. Első kötet (1698-1711). Kapitális Kft., Debrecen, 7-10.

Krepsz Valéria 2015. A kérés beszédaktusa középmagyar kori fönemesek és közrendűek levelezésében. Magyar Nyelv 111: 162-73. https://doi.org/10.18349/MagyarNyelv.2015.2.162

Locher, Miriam A. - Watts, Richard J. 2005. Politeness theory and relational work. Journal of Politeness Research 1: 9-33. https://doi.org/10.1515/jplr.2005.1.1.9

Novák, Attila - Gugán, Katalin - Varga, Mónika - Dömötör, Adrienne 2018. Creation of an annotated corpus of Old and Middle Hungarian court records and private correspondence. Language Resources and Evaluation 52: 1-28. https://doi.org/10.1007/s10579-0179393-8

Sárosi Zsófia 2003. Történeti szociopragmatika - magyar nyelvtörténet más megközelítésben. Magyar Nyelv 99: 434-48.

Sárosi Zsófia 2015. Pragmatika, szociopragmatika, udvariasságkutatás a magyar nyelvtörténetben. Magyar Nyelv 111: 129-47. https://doi.org/10.18349/MagyarNyelv.2015.2.129

Searle, John R. 1975. A taxonomy of illocutionary acts. In: Gunderson, Keith (ed.): Language, Mind and Knowledge. University Minnesota Press, Minneapolis.

Szalai Andrea 2009. Atok, feltételes átok és társadalmi nem erdélyi roma közösségek nyelvi ideológiájában és gyakorlataiban. Doktori (PhD) értekezés. Pécsi Tudományegyetem Nyelvtudományi Doktori Iskola. Pécs. Elérhető: http://pea.lib.pte.hu/bitstream/handle/ pea/15473/szalai-andrea-phd-2011.pdf?sequence=1\&isAllowed=y (Letöltve: 2020. január 14.)

Szili Katalin 2002. A kérés pragmatikája a magyar nyelvben. Magyar Nyelvőr 126: 12-30.

Szili Katalin 2004. Tetté vált szavak. Tinta Könyvkiadó, Budapest.

Takáts Sándor 1910. Szalai Barkóczy Krisztina, 1671-1724. Franklin-Társulat Nyomdája, Budapest.

Tátrai Szilárd 2011. Bevezetés a pragmatikába - Funkcionális kognitív megközelités. Tinta Könyvkiadó, Budapest.

TMK = Történeti magánéleti korpusz: http://tmk.nytud.hu/

\section{Bácsi Enikö \\ PhD-hallgató}

ELTE BTK Nyelvtudományi Doktori Iskola tudományos segédmunkatárs

Nyelvtudományi Intézet 


\title{
SUMMARY
}

\author{
Bácsi, Enikö
}

\section{Variations of request in $17^{\text {th }}$ and $18^{\text {th }}$ century letters}

This paper examines the speech act of request in the letters of Krisztina Barkóczy, a Hungarian noble woman, that she wrote to her husband, Sándor Károlyi at the end of the $17^{\text {th }}$ and the beginning of the $18^{\text {th }}$ century. The research takes a closer look on the subjects of requests, their linguistic presentations and the strategies used in connections with them from the viewpoint of historical sociopragmatics and it explores the connections between them. The base for this research is the classification established by Blum-Kulka, House and Kasper involving nine categories that describe the representation of intention in connection with requests from the most direct to the most indirect.

After discussing the theoretical background and the results of previous researches necessary for analysing the act of request, the examined letters will be presented, then with the help of diagrams, the paper explains the significant differences compared to the modern modes of request and in which way the result show similarities with the research of requests from the $16^{\text {th }}$ and $17^{\text {th }}$ century. Finally, the paper points out to further ways of approach in examining Middle Hungarian request by bringing in the concept (and theory) of relational work.

Keywords: speech act of request, historical sociopragmatics, Middle Hungarian, letters.

\section{A magyar perifrasztikus igeneves szerkezetek spirálelmélete}

\section{Bevezetés}

I've waited a long time for this moment, my little green friend - ezzel a mondattal üdvözli az uralkodó Yoda mestert a Star Wars - A Sith-ek bosszúja címü filmben. A mondat példa arra, hogy mennyire szerves részei a segédige + participium szerkezetek az európai nyelvek TAM-rendszereinek. ${ }^{1}$ Körülnézve a kontinensen, számos participiumos szerkezetet találunk, amelyek formailag és korban is magas fokú sokszínüséget mutatnak: míg a német Perfekt ${ }^{2}$ igeidő immár több mint ezeréves múltra nyúlik vissza, addig a cseh nyelvben most van születőben a már meglévő közös szláv forma mellett egy új, hasonló szerkezet. Ez utóbbi annyira fiatal, hogy jelenleg még nem ismerik el önállónak. Ha megnézzük a finn nyelvet, azt látjuk, hogy

TAM = tense-aspect-mood, azaz idő-aspektus-mód.

2 Jelen dolgozatban az ismertebb nyelvek igeidőit azok eredeti nevével fogom megnevezni, míg a komparatív kategóriákat latinul: a német Perfekt, a svéd perfekt és az angol present perfect egyaránt perfektumok. 